\title{
Angiogenesis: An update and potential drug approaches (Review)
}

\author{
MAEN ABDELRAHIM ${ }^{1,2}$, SANTHI KONDURI ${ }^{1}$, Md. RIYAZ BASHA ${ }^{1}$, \\ PHILIP A. PHILIP ${ }^{3}$ and CHERYL H. BAKER ${ }^{1,2}$ \\ ${ }^{1}$ Cancer Research Institute, M.D. Anderson Cancer Center Orlando, Orlando, FL 32806; \\ ${ }^{2}$ Burnett School of Biomedical Sciences, University of Central Florida, Orlando, FL 32816; \\ ${ }^{3}$ Karmanos Cancer Institute, Wayne State University, Detroit, MI 48201, USA
}

Received July 3, 2009; Accepted August 18, 2009

DOI: 10.3892/ijo_00000470

\begin{abstract}
The therapeutic potential of targeting tumor endothelium and vascular supply is now widely recognized to treat different diseases. One such disease is cancer; where endothelial cells are actively proliferating to support the tumor growth. Solid tumors cannot grow beyond the size of a few millimeters without inducing the proliferation of endothelium and formation of new blood vessels. Hence it is crucial to search for new agents that selectively block tumor blood supply. These include anti-angiogenic molecules, vascular disrupting agents or endothelial disrupting agents. The antiangiogenic molecules such as monoclonal antibodies and tyrosine kinase inhibitors disrupt endothelial cell survival mechanisms and new blood vessel formation, and vascular disrupting agents for instance ligand-directed and small molecules can be used to disrupt the already existing abnormal vasculature that support tumors by targeting their dysmorphic endothelial cells. The recent advances in this area of research have identified a variety of investigational agents which are currently in clinical development at various stages and some of these candidates are already approved in cancer treatment. This report will review some of the recent developments and most significant advances in this field and outline future challenges and directions.
\end{abstract}

\section{Contents}

1. Introduction

2. Anti-angiogenesis strategies

Correspondence to: Dr Maen Abdelrahim, Cancer Research Institute, M.D. Anderson Cancer Center Orlando, 110 Bonnie Loch Ct., Mail Point 47, Orlando, FL 32806, USA

E-mail: maen.abdelrahim@orlandohealth.com

Key words: tumor endothelium, anti-angiogenesis, vascular disrupting agents, cancer therapy
3. Vascular disrupting strategies

4. Combining VDAs with anti-angiogenic drugs

5. Conclusions and future directions

\section{Introduction}

Angiogenesis is essential to maintain closed circulatory system and also for supplying oxygen and nutrients to various tissues in the body $(1,2)$. It is well known that tumors need an ongoing blood supply to grow beyond a minimum size of $2-3 \mathrm{~mm}^{3}$ (3). Tumors start as avascular masses which initially depend on pre-existent vasculature in their microenvironment (4). However, when tumor tissues grow beyond the limit of oxygen diffusion, hypoxia induces vessel growth by signaling through hypoxia inducible transcription factors (HIFs) (5). These factors induce the production of proangiogenic compounds such as vascular endothelial growth factor (VEGF), angiopoietin (Ang)-1, placental growth factor (PlGF), and various cytokines (6).

Targeting tumor vascular supply is widely recognized for its therapeutic potential. A variety of investigational agents have been developed as a result of intense research and development leading to currently available drugs/agents for clinical trials. These novel agents target the endothelium or vasculature of the tumors which make these agents quite distinct from the cytotoxic drugs conventionally used in the treatment of solid tumors. Recently, Chang et al showed that anti-angiogenic targeting liposomes increase therapeutic efficacy of solid tumors and anti-angiogenic ligand-targeted therapy is highly beneficial over conventional anticancer drug therapy (7).

More than $90 \%$ of all cancers present as solid tumors which depend on a functioning vascular network to supply oxygen and nutrients and interfering with this network holds a great promise for cancer therapy. Conventional anticancer treatments exert their effect by targeting the rapidly growing neoplastic cell population; however vascular-targeted therapies elicit an indirect effect on the tumor cells. Targeting a component distinct from the one targeted by cytotoxic agents will provide a great potential for complementary and/or synergistic activity. A significant effect may take place because blockage 
Table I. Differences between anti-angiogenic and vascular disrupting agents. ${ }^{\mathrm{a}}$

\begin{tabular}{llll}
\hline Agents & \multicolumn{1}{c}{ Physiological target } & Stage of disease & Treatment schedule \\
\hline $\begin{array}{lll}\text { Anti-angiogenic agents } \\
\text { Vascular disrupting agents }\end{array}$ & New blood vessel formation & Early stage (preventive action) & Chronic administration \\
\hline
\end{tabular}

${ }^{a}$ Chronic administration of anti-angiogenetic agents target the formation of new blood vessels and which are used in the early stages of disease which could impacts in the prevention or spreading of the disease, while vascular disrupting agents target established blood vessels and their acute administration is beneficial in advanced stage of the disease.

or destruction of a single blood vessel may result in tumor cell starvation and death. In some tumors, the endothelial cell does not need to be directly killed by the drugs; a change of structure or local initiation of the coagulation cascade may be all that is needed. In addition, endothelial cells are normal, untransformed cells and therefore have greater genetic stability than the neoplastic cells and are less likely to acquire drug resistance (8).

Vessel ligation and transcatheter arterial embolization are examples of early attempts to interfere with tumor blood supply (9). Even though these approaches were invasive and are associated with a number of non-selective effects resulting in normal tissue damage, they provide clear evidence that the vasculature is a possible target to inhibit solid tumor growth. Recent developments in this therapeutic area have now resulted in a wide variety of selective agents with known targets.

Generally, there are two approaches to target the vasculature of a tumor. The first approach is to target and inhibit new blood vessel formation in tumors by anti-angiogenic agents $(8,10-14)$. The second approach is to target and destroy existing tumor blood vessels by vascular disrupting agents (VDA) (15-20). These agents differ from each other in three major aspects: physiological target, the stage of disease, and the treatment scheduling (Table I).

\section{Anti-angiogenesis strategies}

Angiogenesis is the formation of new blood vessels from the pre-existing ones and it is a physiological process in embryogenesis and development. During adulthood the proliferation rate of endothelial cells is usually very low compared to other cell types (21) except in wound healing and in the endometrium and ovaries where physiological angiogenesis takes place. However, pathological angiogenesis is observed in a variety of disorders such as diabetic retinopathy, rheumatoid arthritis, atherosclerosis, psoriasis, as well as in solid tumors and metastasis. Tumor angiogenesis is an extremely complex process. It is under dynamic regulation by stimulatory [e.g., VEGF, platelet-derived growth factor (PDGF), basic fibroblast growth factor (bFGF), interleukin-8 (IL-8), matrix metalloproteinases (MMPs)] and inhibitory [e.g., tumor necrosis factor (TNF), serotonin (5HT), nitric oxide, angiostatin or endostatin] factors released by tumor and host cells.

In tumors, cells are initially oxygenated and nourished by simple diffusion, but when tissues grow beyond the limit of oxygen/nutrient diffusion, the tumor microenvironment changes and the tumor cells become dominant with hypoxia, hypoglycaemia, bicarbonate depletion, hypercapnia, high lactate levels and acidosis (22). For further growth, tumors must develop an angiogenic phenotype. Tumor angiogenesis involves several processes, including proliferation of endothelial cells, proteolytic degradation of the extracellular matrix and migration of endothelial cells, leading to the formation of a functioning vessel with a lumen (23).

In the last few years, different strategies have been used to inhibit angiogenesis which resulted in new candidate molecules that have been tested in preclinical and clinical trials. The use of antibodies showed that antibody therapy was effective and promising. In addition, small molecules, mainly inhibitors of receptor tyrosine kinases, have been designed and their potential effect for tumor therapy is currently under investigation. In principle, both approaches can inhibit angiogenic processes. While monoclonal antibodies can sequester molecular mediators such as VEGF-A, small organic molecules can interfere with intracellular signaling and protein expression. The two molecular approaches are likely to be complementary, as they act at the level of different molecular targets.

a) Monoclonal antibodies. Because monoclonal antibodies have high affinity and specificity, some may be given in high doses; higher than expected and therefore, represent a class of safe therapeutic agents that can easily be combined with standard chemotherapeutic regimens. Monoclonal antibody derivatives have shown an impressive selectivity by localizing around tumor blood vessels and mediating tumor therapy in animal models of cancer. Recent advances in proteomic research have made it possible to screen for selective molecular targets on the endothelium and vasculature of tumors. In this section we will discuss some of these important targets.

i) VEGF/VEGF-receptors. VEGF (particularly VEGF-A) is considered as the most important and potent pro-angiogenic (survival) factor involved in tumor growth and metastasis (24). Expression of VEGF mRNA is induced by different growth factors and cytokines, including platelet derived growth factor PDGF, epidermal growth factor EGF, TNF- $\alpha$, transforming growth factor TGF- $\beta$ and IL-1ß (21). VEGF-A promotes blood vessel formation by binding and activating VEGF receptor 2 (VEGFR2/KDR) and at the same time increases vascular permeability and contributes to endothelialcell survival and proliferation in blood and lymphatic vessels. 
Application of antibodies targeting either VEGF-A or VEGFR-2 is a promising strategy to block VEGF-A function. In 2004, the Food and Drug Administration (FDA) approved a recombinant humanized antibody bevacizumab (Avastin, Genentech/Roche) which targets all isoforms of human VEGF-A. Phase II clinical trials have been conducted in a wide range of malignant diseases focusing mainly on colorectal cancer (CRC), which shows high expression of VEGF and its receptors (25).

Phase III clinical trials were conducted in untreated, metastatic CRC and bevacizumab in combination with irinotecan/5-fluorouracil chemotherapy was compared to chemotherapy alone. The duration rate of therapeutic response, progression-free survival and overall survival was significantly improved by bevacizumab compared with placebo (26). A phase III study in breast cancer patients showed that bevacizumab combined with capecitabine has a highly significant increase of overall-response-rate but no effect on progression-free survival when compared with capecitabine alone (27). Bevacizumab was also investigated for its efficacy in the treatment of other cancers including breast cancer, lung cancer and hematological cancers $(28,29)$.

In October 2006, FDA granted a labeling extension to bevacizumab for the treatment of advanced stage non-small cell lung cancer (NSCLC) along with carboplatin and paclitaxel (30). The addition of bevacizumab to first-line chemotherapy improved response rate and progression-free survival among the patients with advanced stage NSCLC. A randomized phase II trial of patients with newly diagnosed advanced NSCLC treated with standard platinum based chemotherapy with placebo or bevacizumab (at either 7.5 vs. $15 \mathrm{mg} / \mathrm{kg}$ ) demonstrated a higher response rate and increase in overall survival with the higher dose of bevacizumab compared to placebo $(30,31)$.

Another humanized monoclonal antibody that targets isoforms 121 and 165 of VEGF-A has been developed and investigated. This antibody is called HuMV833 and has shown to localize to tumor metastases in patients in a PET experiment (32). Recently, a phase I dose escalation study was performed on patients with advanced cancer and has demonstrated good tolerability and even some clinical activity (33). In addition to the previous antibodies, a murine VEGF antibody has been designed (2C3). It is an IgG2a that inhibits the binding of VEGF to VEGFR2 but not to VEGFR1 (34). However, comparison efficacy and toxicity studies of the humanized version of $2 \mathrm{C} 3$ with less specific antibodies have not been investigated yet.

The VEGF-trap is a different antibody approach that has been used to inhibit VEGF activity. It is a fully humanized soluble composite decoy receptor generated by fusing the extra-cellular domains of VEGFR-1 and VEGFR-2 to the Fc portion of human IgG1 (35). This decoy not only binds to VEGF-A but also to PIGF and VEGF-B. In vivo studies using mice xenograft models treated with VEGF-trap have shown promising results (36). In addition, a phase I clinical dose escalation study showed acceptable tolerability (37); however, the efficacy of VEGF-trap in cancer treatment needs to be proven (38). Another important target in the VEGF pathway is VEGFR-2. In the last few years, a new human antibody (IMC-1121) has been designed to target VEGFR-2. This antibody prevents VEGF binding and therefore the receptor downstream signaling (39). The IMC-1121 antibody has been shown to significantly prolong survival of animals grafted with human leukemia cells (40).

ii) EGFR2 (HER2-receptor). It has been shown that the EGF receptor 2 protein (HER2; ErbB2) is overexpressed in $30 \%$ of breast cancer patients and this amplification correlates with poor clinical prognosis $(41,42)$. HER2 is implicated in the over-expression of VEGF through hypoxia-inducible factor 1 alpha $(\mathrm{HIF} 1 \alpha)$ under hypoxic conditions and even through hypoxic-independent mechanisms (43). A humanized monoclonal antibody to the extracellular domain of the HER2 receptor (Trastuzumab, Herceptin) is currently being used to treat breast cancer patients $(44,45)$. The antibody binds to HER2 which then lead to internalization and thereby downregulation of the receptor, inhibition of cell cycle progression, and antibody-dependent cellular cytotoxicity by inducing an immune response (46). Trastuzumab has been shown to inhibit angiogenesis in both the in vitro (47) and in vivo models $(48,49)$.

Pertuzumab (Omnitarg, 2C4) is another antibody to the HER2 tyrosine kinase receptor that has entered clinical trials (42,50-53). A phase I study showed that pertuzumab is clinically active and well tolerated (51) and was then further investigated in phase II trials for ovarian, lung and prostate cancers (42). A synergistic effect of trastuzumab and pertuzumab has been shown in in vitro studies in breast cancer cells (51).

iii) Integrins. Inhibition of the adhesive interaction of vascular endothelial cells during angiogenesis represents another target for the endothelial cells and anti-angiogenesis therapy. Integrin $\alpha \mathrm{v} B 3$ is a member of a large family of cell surface proteins that mediate cell-matrix and cell-cell interactions. Studies have shown that this protein plays an important role and is upregulated during angiogenesis (54). A murine antibody, LM609, to the vitronectin receptor integrin $\alpha \mathrm{v} B 3$ selectively localized to blood vessels in a breast cancer model and was able to localize at the tumor site in a magnetic resonance imaging setup in rabbits (55). In addition, LM609 significantly inhibited tumor growth when administered intravenously to tumor-bearing mice. Analysis of treated tumors showed significantly fewer blood vessels, suggesting an anti-angiogenic effect of the tested compound (56). Another approach has been used to target integrin avß3 using tripeptide RGD which selectively recognizes the vitronectin receptor and localizes to tumor blood vessels in vivo $(57,58)$.

These findings have been used to design a fusion protein containing the RGD sequence and the Fc-fragment of a mouse $\mathrm{IgG}$ in order to target the tumor endothelium thereby eliciting an anti-angiogenic immune response. It has been demonstrated that the fusion protein inhibited tumor angiogenesis and tumor growth in vivo and improved overall survival in animals (50).

b) Small molecules (inhibitors of receptor tyrosine kinases and others). Receptors for VEGF are members of the tyrosine kinase family and were initially identified on endothelial cells (59). There are three members of the VEGF receptor family: VEGFR-1(Flt), VEGFR-2 (Flk/KDR) and VEGFR-3 (Flt4). All three are receptor-type tyrosine kinases, which are expressed primarily, though not exclusively, by endothelial 
cells. The first two bind the classical VEGF (VEGF A) and the latter interacts with VEGF C and D. At present, the mitogenic actions of VEGF are thought to be mediated primarily by VEGFR-2. VEGFR-1 binds the ligand with a greater affinity than VEGFR-2. An alternatively spliced form of VEGFR-1, lacking the seventh immunoglobin-like structure and both the transmembrane and cytoplasmic domains, has been identified in human umbilical vein endothelial cells (HUVEC) cells. Since this receptor binds VEGF with high affinity and prevents VEGF-induced mitogenesis, it may represent a negative regulator of angiogenesis. Following receptor activation in endothelial cells, a number of cellular responses occur that are likely to play a role in angiogenesis and tissue remodeling. For example, induction of urokinase and urokinase receptors, tissue plasminogen activators (PA), PA inhibitors, metalloproteinase activity, vascular cell adhesion molecule-1 and intercellular adhesion molecule-1 expression and hexose transport $(60,61)$. One of the strategies for antagonizing VEGF-induced angiogenesis is to inhibit the kinase activity of its receptor. This has been shown to be a promising therapeutic approach to stabilize the progression of solid malignancies by abrogating tumor-induced angiogenesis. In the last few years several kinase inhibitors have been investigated in preclinical and clinical aspects.

i) $A Z D 2171$ is an indole-ether quinazoline receptor kinase inhibitor. Wedge and co-workers have shown that AZD2171 is a potent ATP competitive inhibitor of recombinant KDR tyrosine kinase in vitro (62). Concordant with this, in HUVEC, AZD2171 inhibited VEGF-stimulated proliferation and KDR phosphorylation. In a fibroblast/endothelial cell co-culture model of vessel sprouting, AZD2171 also reduced vessel area, length and branching. Similarly, the growth of established human tumor xenografts (colon, lung, prostate, breast and ovary) in athymic nude mice was inhibited in a dose-dependent manner by AZD2171 with chronic administration (62).

ii) $B A Y 43-9006$ is a bi-aryl urea that can significantly inhibit Raf-1, a member of the RAF/MEK/ERK signaling pathway. The RAS/RAF signaling pathway is one of the important mediators of tumor cell proliferation and angiogenesis. BAY 43-9600 has been shown to be a novel dual inhibitor of RAF and VEGFR-2 that targets tumor cell proliferation and angiogenesis (63).

It has been demonstrated that BAY 43-9006 has significant activity against several receptor tyrosine kinases involved in neo-vascularization and tumor progression, including VEGFR-2, VEGFR-3, PDGFR- $\beta$, Flt-3 and c-Kit. After potent inhibition of VEGFR-2, PDGFR- $\beta$, and VEGFR-3 cellular receptors auto-phosphorylation was also observed for BAY 43-9600. In xenograft models, it has been shown that daily administration of BAY 43-9600 demonstrated broad spectrum anti-tumor activity in colon, pancreatic and breast tumor cell lines expressing mutant KRAS, wild-type or mutant BRAF. In sharp contrast, non-small cell lung cancer cell lines expressing mutant KRAS were insensitive to inhibition of the mitogen activated protein kinase pathway by BAY 43-9600.

iii) $C P-547,632$ is an isothiazole tyrosine kinase inhibitor of VEGFR-2 and FGF kinases. One study has shown that CP-547,632 can inhibit VEGF stimulated auto-phosphorylation of VEGFR-2. The same study also reported that after oral administration of CP-547,632 to mice bearing NIH3T3/H-ras tumors, VEGFR-2 phosphorylation was inhibited in a dosedependent fashion (64).

iv) CEP-7055 is the fully synthetic orally active N,Ndimethyl glycine ester of CEP-5214, a C3-(isopropylmethoxy) fused pyrrolocarbazole with potent pan-VEGFR kinase inhibitory activity. CEP-5214 has been shown to inhibit VEGFR2/KDR kinase, VEGFR1/FLT-1 kinase and VEGFR3/ FLT-4. In HUVEC, VEGF-stimulated VEGFR2/KDR autophosphorylation was inhibited by CEP-5214. In addition, CEP-5214 revealed a dose-related inhibition of microvessel growth ex vivo in rat aortic ring explant cultures (65).

v) $P T K 787 / Z K 222584$ [1-(4-chloroanilino)-4(4-pyridylmethyl) phthalazine succinate] is another potent inhibitor of VEGFR tyrosine kinases. It inhibits other class III kinases, such as the PDGFR- $\beta$ tyrosine kinase, c-Kit and c-Fms. However, PTK787/ZK 222584 shows no inhibitory activity against EGFR, FGFR-1, c-Met, Tie-2 or intracellular kinases such as c-Src, c-Abl and protein kinase C- $\alpha$. PTK787/ZK 222584 inhibits VEGF-induced autophosphorylation of the kinase insert domain containing receptor (KDR) endothelial cell proliferation, migration and survival in nanomolar range in cell based assays. PTK787/ZK222584 does not have any cytotoxic or anti-proliferative effects on cells that do not express VEGF receptors. In animal models, it has been shown that oral administration of PTK787/ZK 222584 can inhibit VEGF and PDGF-induced angiogenesis (66).

vi) KRN633 is a selective tyrosine kinase inhibitor for VEGFR-1, -2 and -3. It has been shown that KRN633 also inhibits the activation of mitogen-activated protein kinases by VEGF, along with HUVEC proliferation and tube formation. In the in vivo tumor xenograft model in mice and rats, KRN633 was able to inhibit the growth of lung, colon and prostate tumors (67).

vii) $S U 11248$ is a novel small molecule receptor tyrosine kinase inhibitor with direct anti-tumor as well as antiangiogenic activity via targeting VEGF, PDGF, KIT and FLT3 receptor tyrosine kinases. SU11248 is able to exert direct anti-tumor activity against tumor cells that rely on RTKs for proliferation and/or survival, but is also able to indirectly inhibit tumor growth by inhibiting angiogenesis. Anti-tumor activity of SU11248 in mouse xenograft models was investigated and target phosphorylation was measured and correlated with plasma inhibitor levels. It has been shown that SU11248 selectively inhibited Flk-1/KDR (VEGF receptor-2) and PDGFR- $\beta$ phosphorylation (in a time- and dose-dependent manner) when plasma concentrations of inhibitor reached or exceeded $50-100 \mathrm{ng} / \mathrm{ml}$. In mouse xenograft models, SU11248 exhibited broad and potent anti-tumor activity causing regression, growth arrest, or substantially reduced growth of various established xenografts derived from human or rat tumor cell lines. The pharmacokinetic/ pharmacodynamic relationship established for SU11248 in the preclinical studies has aided in the design, selection and evaluation of dosing regimens in human trails (68).

viii) $Z D 6474$ (Zactima) is a heteroaromatic substituted anilinoquinazoline that acts as a potent inhibitor of the VEGFR2 tyrosine kinase activity (69-71). This agent also has activity against the EGFR tyrosine kinase (70) but to a far lesser extent. The efficacy of combining ZD6474 (Zactima) with single and fractionated dose radiation exposures was 


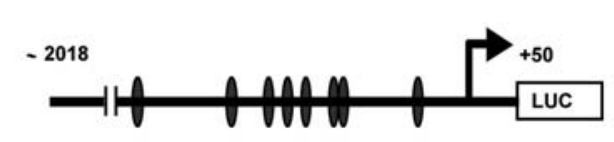

pVEGF1

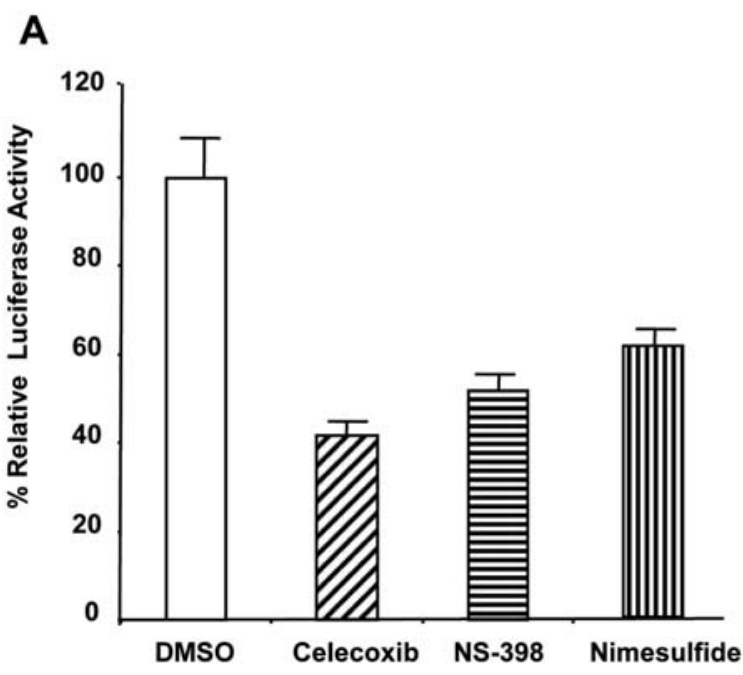

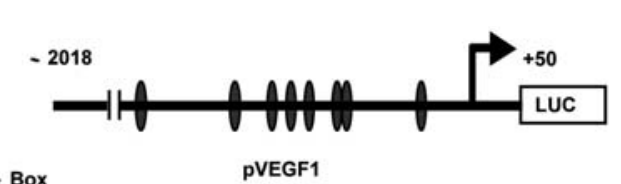

B

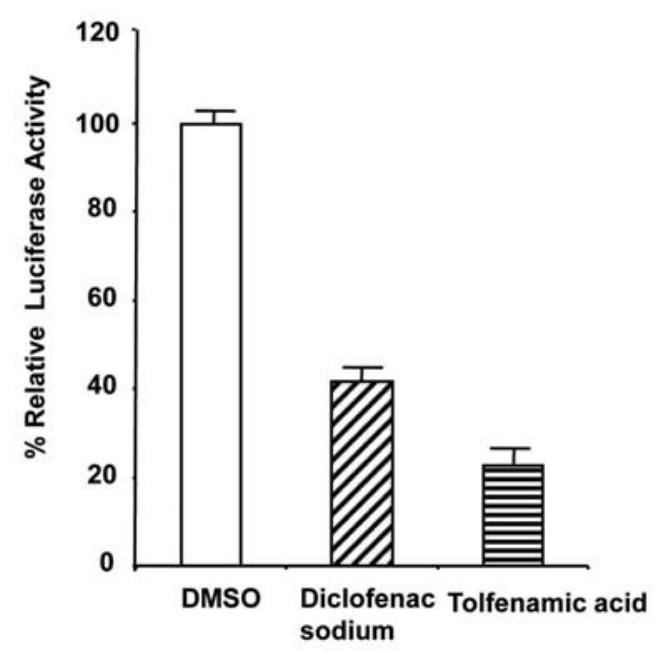

Figure 1. Effect of NSAIDs and COX-2 inhibitors on VEGF expression in cancer cells. (A) SW480 colon cancer cells were transfected with VEGF promoter constructs, treated with the COX-2 inhibitors celecoxib (Cel), nimesulfide (NM), or NS-398 (NS), and luciferase activity was determined (91). (B) Panc-1 pancreatic cancer cells were transfected with the same construct and treated with tolfenamic acid and a structurally related compound (Diclofenac sodium) (92). Decreased activity was observed in all treatment groups compared to the vehicle treated groups (DMSO control).

examined in a human colorectal carcinoma model using HT29 cells. ZD6474 increased the response of HT29 xenografts to both single and fractionated dose radiotherapy. This study indicates that ZD6474, when used in conjunction with radiation therapy, has a clear therapeutic advantage providing a rationale for considering the combination of this agent with radiotherapy in the clinic. In one in vivo study, ZD6474 has been shown to significantly reduce the vessel density in treated tumors. It has a bioavailability profile consistent with chronic, oral administration and is currently undergoing clinical trials $(72,73)$. In human tumor xenograft models of diverse tissue (lung, breast, prostate, colorectal, vulval) origin, chronic (once daily) administration of ZD6474 led to dose-dependent inhibition of tumor growth $(71,74)$. It was also reported in the xenograft model that ZD6474 has high activity against several central nervous system tumors including gliomas (75). While there have been some recent drawbacks in the development of tyrosine kinase inhibitors (e.g., PTK/ZK; Schering/Novartis), a number of novel members of the same class have shown promising effects in clinical trials and some have been approved for clinical use. SU11248/sunitinib (Sutent) and BAY-43-9006/sorafenib (Nexavar) are example of tyrosine kinase inhibitors that have been approved recently as monotherapies for kidney cancer $(76,77)$.

Small molecules, other than tyrosine kinase inhibitors, can also target angiogenesis pathways and have been investigated. These molecules can target the VEGF pathway indirectly by inhibiting VEGF and/or VEGFR protein expression. Hypoxia is a major pathway for regulation of VEGF expression in tumor and non-tumor tissue (78-80) in part because of upregulation of hypoxia-inducible factor- $1 \alpha$ (HIF- $1 \alpha)$. HIF- $1 \alpha$ forms a transcriptionally active HIF- $1 \alpha-\mathrm{HIF}-1 \beta$ complex that interacts with a distal hypoxia-responsive element in the VEGF gene promoter. Enhanced VEGF expression in cells/tissues has also been linked to other factors, including cytokines, mitogens, activation of kinase signaling pathways, oxidative stress, and hormone stimulation (81-85). It has been shown that enhanced VEGF stimulation by some of these factors involves direct or indirect activation of members of the specificity protein (Sp) family bound to one or more GC-rich motifs located in the proximal region of the VEGF promoter $(81,82,84,85)$. For example, PDGF-enhanced expression of VEGF in NIH3T3 cells involves Sp1 and Sp3 bound to the -85 to -50 region of the VEGF promoter (81). Oxidative stress-induced activation of kinases enhances VEGF expression in gastric cancer cells through increased Sp1-dependent activation of the same proximal GC-rich sites (84). Stoner and co-workers have shown that hormone-induced VEGF expression in ZR-75 breast cancer cells required ER $\alpha / \mathrm{Sp} 1$ and $\mathrm{ER} \alpha / \mathrm{Sp} 3$ interactions with the proximal GC-rich VEGF promoter elements (85). A recent study (86) further investigated the role of $\mathrm{Sp} 1$ and other $\mathrm{Sp}$ proteins in regulation of VEGF and proliferation of human pancreatic cancer cells. The results of the VEGF studies confirm that the proximal GC-rich sites are required for expression of VEGF; however, the results of RNA interference studies showed that multiple Sp proteins are involved in VEGF regulation. Sequential knockdown of Sp1, Sp3 and Sp4 showed that all three proteins regulated transactivation of VEGF promoter. Sp4 expression has not been extensively investigated in cancer cells, and these results suggest that the angiogenesis and metastatic potential of pancreatic tumors may also be dependent on levels of Sp4. These and other studies have shown a direct 
linkage between expression of $\mathrm{Sp}$ proteins in various tumors, VEGF overexpression and have suggested that Sp proteins can be important targets for new anti-angiogenic agents.

In the last few years several strategies have been used to target $\mathrm{Sp}$ in several tumors. For example, Ishibashi and coworkers transfected Sp1 decoys(GC-rich oligodeoxynucleotide) into human lung A549 adenocarcinoma and human glioblastoma multiform U251 cancer cell lines and inhibited TNF $\alpha$-induced VEGF gene/protein expression (87).

In addition, cyclooxygenase 2 (COX-2) inhibitors such as celecoxib are being developed as anticancer drugs, and there is considerable evidence showing that these compounds exhibit anti-angiogenic activity $(88,89)$. A recent study has linked the anti-angiogenic effects of celecoxib in pancreatic cancer cells to modulation of $\mathrm{Sp} 1$ transcription factor activity (90). This study showed that celecoxib inhibited pancreatic tumor growth and decreased liver metasasis in an athymic nude mouse model, and this was paralleled by growth inhibition and decreased VEGF protein expression in pancreatic cancer cells.

These observations suggest that the anti-angiogenic activity of celecoxib in pancreatic cancer cells is linked to targeted dephosphorylation of Sp1. Ongoing research (91) has also investigated the mechanisms of action of COX-2 inhibitors and non-steroidal anti-inflammatory drugs (NSAIDs) and their effects on cancer cell proliferation and VEGF expression in colon, pancreatic and other cancer cell lines. The growth inhibitory effects of these compounds are accompanied by downregulation of activity in colon cancer cells transfected with various pVEGF constructs (Fig. 1A), and this was accompanied by decreased expression of Sp1 and Sp4 but not Sp3 proteins. Since regulation of VEGF is dependent on $\mathrm{Sp} 1, \mathrm{Sp} 3$ and $\mathrm{Sp} 4$, results show that decreased expression of VEGF in SW-480 and other colon cancer cells treated with celecoxib, nimesulfide or NS-398 is due to downregulation of Sp1 and Sp4. It was also shown that decreased Sp1/Sp4 by COX-2 inhibitors/NSAIDs in colon cancer cells was COX-2independent and due to activation of proteasomes which specifically target degradation of Sp1 and Sp4 (91). These results suggest that further development of this degradation pathway and its specificity may be an important new approach for drug-induced inhibition of angiogenesis.

Recent studies from our group showed that Tolfenamic acid and structurally related biaryl derivatives induced degradation of specific Specificity protein $(\mathrm{Sp})$ transcription factors, $\mathrm{Sp} 1, \mathrm{Sp} 3$, and $\mathrm{Sp} 4$ in pancreatic cancer cells and inhibited VEGF mRNA and protein expression; this inhibition was associated with the decreased Sp-dependent activation of the VEGF promoter (Fig. 1) (92). In orthotopic mouse model for pancreatic cancer, treatment with tolfenamic acid $(50 \mathrm{mg} / \mathrm{kg}$ of body weight) significantly decreased the tumor size; tumor weight (Fig. 2); VEGF expression; blood vessels density (Fig. 3) and liver metastasis (92,93). Currently tolfenamic acid is in phase I clinical trials at M.D. Anderson Cancer Center Orlando to test on patients with upper gastrointestinal cancers.

\section{Vascular disrupting strategies}

Tumor endothelial cells proliferate more rapidly than their counterparts in normal tissues and it has been proposed that
A

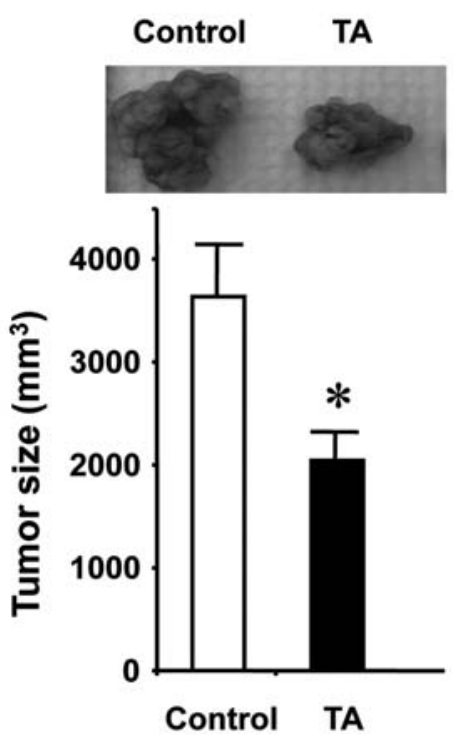

C

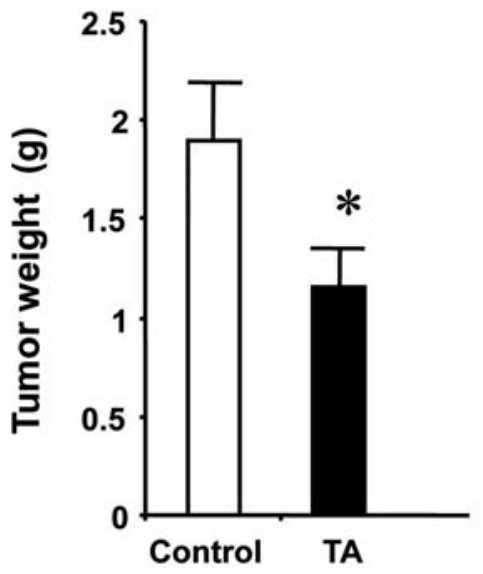

Figure 2. Tolfenamic acid decreased the tumor formation in orthotopic pancreatic mice. Athymic nude mice were injected with L3.6 pl cells orthotopically and treated with tolfenamic acid $(25 \mathrm{mg} / \mathrm{kg}$ ) or vehicle (control group) for 4 weeks. Tumor volume and weights were analyzed and it was found that tolfanamic acid treatment resulted a significant decrease in both the tumor size and weight (93).

the properties of tumor endothelium may be different from normal tissue. These differences could be exploited by selective drugs or agents, now called vascular disrupting agent (VDAs) or vascular targeting agents (VTA) (94). Several reports have shown that biological differences between normal and tumor vascular endothelium (Table II) can provide a scientific rationale for vascular targeting and therapeutic benefits (37,94-101). Multiple tumor endothelial markers that are not expressed on normal vascular endothelium are now being characterized and used for specific targeted purposes (97). The target of VDAs is either the endothelial cells lining tumor vessels or a protein produced by the tumor endothelium $(58,102)$. Anti-tumor effects in this situation are mediated by either induction of the endothelial and subsequent tumor cell apoptosis or by hemorrhagic necrosis as a result of vascular shutdown $(95,103)$.

Two classes of VDAs are being developed. The first class is ligand-based, which utilize antibodies and peptides to deliver toxins, pro-coagulant or pro-apoptotic effectors to tumor-associated vessels. In the second class, small molecules 


\section{Control}

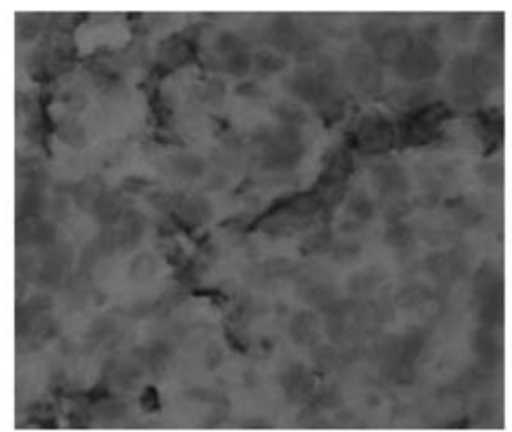

Tolfenamic acid

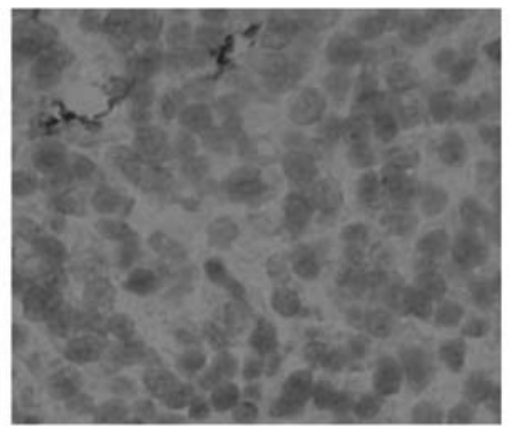

Figure 3. Reduction of blood vessel density in a pancreatic tumor by tolfenamic acid. In an orthotropic model of human pancreatic cancer (athymic nude mice injected with L3.6 pl cells), mice were treated with vehicle (corn oil) or with tolfenamic acid by oral gavage for 4 weeks. Staining with antibodies to determine microvessel density showed decreased CD31 staining in tumors from mice treated with tolfenamic acid when compared to tumors from vehicle treated (control) animals. These results demonstrate that tolfenamic acid exhibits anti-angiogenic activities in pancreatic cancer tumors.

Table II. Differences between tumor and normal endothelium/ vasculature. ${ }^{\mathrm{a}}$
Constant remodeling of tumor vessels
Increased vessel tortuosity
Lack of associated pericytes
Reliance on a tubulin cytoskeletal network for functional integrity
Vessels thin walled and fragile
Increased interstitial pressure within tumor
Vessel marker immaturity
Greater vascular permeability
Variable flow rates
Huge variability in vascular density
Lack of vascular smooth muscle
Lack of lymphatic drainage
Abnormalities of endothelial cell shape and function

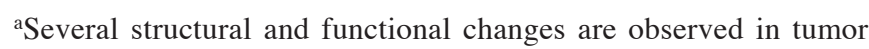
endothelium/vasculature which impacts the tumor growth and metastasis. A variety of characteristic changes occur due to tumor formation are given in the table (37,94-101).

do not specifically localize to such vessels, but exploit the differences between normal and tumor endothelium to induce selective vascular dysfunction and shutdown of tumor blood vessels. Both types of VDA produce a characteristic pattern of central necrosis, leaving a peripheral rim of viable tumor cells (104-108).

a) Biological vascular-disruptive agents (ligand-directed). In this approach, a targeting molecule, such as an antibody or growth factor, is coupled with a toxin or pro-coagulant (e.g., ricin or gelonin) and is used to selectively track these agents to tumor endothelium. Different and unique surface markers are expressed on vascular endothelial cells of different tissues, therefore the development of drugs to selectively target tumor endothelium is quite possible and promising (15). Several possible target molecules (6) are overexpressed on the tumor endothelium and these include targets involved in angiogenesis and remodeling (e.g., VEGF receptors, fibronectin ED-B domain, avB3 integrin) (10); cell-adhesion molecules, which are induced by inflammatory mediators secreted by tumors and normal cells (e.g., vascular cell adhesion molecules (VCAM-1), E-selectin, N-cadherin) and targets (5) associated with pro-thrombotic changes that occur on tumor endothelium (e.g., phosphatidylserine, a tumor endothelium surface phospholipid). The possible outcome of such treatment includes thrombosis within tumor vasculature caused by direct injury or apoptosis, initiation of an immune attack on the tumor vasculature or a change of conformation of the tumor endothelium, which leads to occlusion of the tumor vessels.

Many different approaches to target endothelial cells, including the use of endothelial cell-specific promoter elements and vectors with restricted cellular tropisms, have been explored and show promising results $(109,110)$. In one study, IL-12 was coupled to humanized IgG antibody to the fibronectin ED-B domain and this showed anti-vascular activity in pre-clinical models (111). Another study showed that monoclonal antibody 3G4, to phosphatidylserine, localizes to the tumor endothelium in pre-clinical models, and enhances the efficacy of docetaxel against human breast carcinoma cell lines with $50 \%$ regression (112). In addition, integrins and aminopeptidase $\mathrm{N}$ are thought to be critical for malignant vasculature and angiogenesis, since inhibitors of these proteins possess anti-tumor activity. In one study, it has been suggested that phage libraries can be used to determine specific peptide sequences of integrins, which allow phages to localize to specific organs (113). These peptide sequences are known as 'vascular addresses' and expected future research in this area may lead to the development of 'organ-specific' VDAs. Several other approaches are in pre-clinical development and these includes VEGF121-gelonin conjugate, a tumor vesseltargeted liposome to CD31 and duramycin-IgG conjugate targeted to phosphatidylethanolamine on tumor blood vessels (56). 
b) Small molecule vascular-disruptive agents. It was noted early on in the clinical evaluation of several compounds including anti-neoplastic agents that some of these drugs can induce vascular damage within tumors, but only at doses approximating the maximum tolerated dose (MTD) which has limited their clinical application (40,114-123). However, several new vascular targeting agents are now in clinical development since they are active at doses less than one-tenth of the MTD used in murine models (124). Small-molecule VDAs are divided primarily into two classes: agents that target tubulin/microtubules (e.g., colchicine, podophyllotoxin, and the vinca alkaloids vincristine and vinblastine), and other anti-neoplastic agents that don't target tubulin/microtubules (e.g., TNF- $\alpha$, flavone acetic acid, and related compounds).

c) Tubulin-targeting agents. Interest in the vascular-damaging aspects of tubulin binding agents was initiated by studies with colchicines and vinca alkaloids, which demonstrated that these agents could induce vascular shutdown in preclinical tumor models, albeit at near toxic doses $(16,115,119,125)$. However, new compounds of this class have now been developed and used at lower and more therapeutic relevant doses. The following are some of these compounds that have been investigated recently.

i) Combretastatin A4 phosphate (CA4P) is a natural compound that has been isolated from a South African tree called Combretum caffrum. This tubulin inhibitor is a prodrug that is rapidly dephosphorylated to the active compound CA4 which is structurally similar to colchicines and binds the colchicine-binding site on tubulin and inhibits tubulin polymerization $(66,126-128)$. Unlike colchicine and other tubulin binding agents (vincristine and vin blastine), CA4P can induce vascular collapse within tumors at doses less than one-tenth of the MTD in murine models (124). These preclinical data have demonstrated selective activity of CA4P against proliferating endothelial cells in vitro. In addition, in vivo data have shown a rapid shutdown of tumor vasculature with resultant central tumor necrosis.

A recent study has demonstrated evidence of an additional mechanism through which $\mathrm{CA} 4 \mathrm{P}$ can selectively disrupt the new abnormal vasculature associated with disease processes (129). These studies showed that CA4P can selectively disengage vascular endothelial (VE)-cadherin interactions between adjacent endothelial cells. Vascular endothelial cadherin is a factor that supports the tumor's neo-vessels and functions to enhance endothelial cell migration, survival, vascular integrity, and assembly into tubular structures. The disengagement of VE-cadherin interaction can lead to endothelial cell detachment and apoptosis. The important aspect of this study was that disengagement only occurred in endothelial cells that lacked smooth muscle cell contact. It is known that the lack of smooth muscle or pericyte support is a feature of a neovasculature associated with disease processes.

A phase I trial of CA4P has been reported in patients with advanced solid tumors (130). Data have shown that CA4P and its active metabolite CA4 displayed dose-dependent linear increase in the area under the curve (AUC) with $0.47 \mathrm{~h}$ half-life of CA4P and $4.2 \mathrm{~h}$ for CA4. At the dose level of $60 \mathrm{mg} / \mathrm{m}^{2}$ six of the seven patients had a significant decline in the gradient peak tumor blood flow. CA4P demonstrated clinical benefit with a sustained complete response in a patient with anaplastic thyroid cancer, a minor response in a patient with non-small-cell lung cancer, and prolonged stable disease for more than a year in three patients with colon, medullary thyroid, and renal cancers. Another phase I pharmacodynamic trial of CA4P in patients with advanced solid tumors has been performed attempting to obtain an optimal biological dose for CA4P (131). These data have suggested that the optimal biological dose for a phase II trial of CA4P is $52 \mathrm{mg} / \mathrm{m}^{2}$. This dose level is below the MTD of $68 \mathrm{mg} / \mathrm{m}^{2}$ but was able to achieve the biological effect of sustained reduction in tumor blood flow.

A synthetic derivative of CA4P (AVE8062) has been synthesized and studied in several tumor models. Preclinical data have demonstrated that AVE8062 can inhibit microtubule polymerization causing rapid vascular shutdown of tumor blood flow in (Lejune, Proc Am Assoc Cancer Res 43, abs. 781, S156, 2002). However, early clinical results of AVE8062 have not yet been reported.

ii) TZT-1027 is another tubulin binding agent that inhibits microtubule assembly. It is a cytotoxic dolastatin-10 analog. It has been demonstrated in in vivo models that TZT-1027 causes rapid tumor vascular collapse by a direct effect on microtubules (132).

A phase I clinical trial has been conducted with TZT-1027 in patients with advanced solid tumors (133). Data has shown that $33 \%$ of patients treated with TZT-1027 had stable disease as defined by RECIST criteria. Another phase I trial of TZT-1027 in 17 patients treated on days 1 and 8 of a 3-week course was reported (134). A partial response within 50 weeks of treatment in a patient with metastatic liposarcoma was observed. In a phase I study of TZT-1027 with carboplatin has shown that there was one partial response seen in a patient with pancreatic carcinoma, and seven patients had stable disease (Blagen, Proc ASCO 23, abs. 3141, S226, 2005).

iii) $M N-029$ is a pro-drug that is converted in vivo to the active compound MN-022 by enzymatic hydrolysis. MN-029 inhibits tubulin polymerization by attaching to the colchicine binding site, resulting in the disruption of the cytoskeleton. This disruption of proliferating endothelial cells leads to tumor ischemia and necrosis (118).

iv) ZD6126 is another VDA that has been shown to interfere with the microtubular network of proliferating endothelial cells supplying tumor vasculature $(106,135)$. A phase I trial of a single 10-min infusion of ZD6126 on day 1 and day 28 revealed that ZD6126 is rapidly metabolized to its active metabolite ZD6126 phenol (Scurr, Proc ASCO 22, abs. 3083, $\mathrm{S} 215,2004)$. Another trial has been conducted to assess the effect of ZD6126 on tumor vasculature. Data have clearly shown that the overall tumor enhancement curve (as assessed by DCE-MRI) was decreased $13-84 \%$ from baseline values at $6 \mathrm{~h}$ after ZD6126 infusion in five of six patients. However, most of the effects were seen at the tumor center (DelProposto, Proc ASCO 20, abs. 440, S111, 2002).

d) Flavanoids and derivatives. Flavanoids such as flavone acetic acid (FAA) and its derivative, 5,6 dimethylxanthenone4-acetic acid (DMXAA, Antisoma plc/Roche Holding AG) are believed to exert their effects on blood vessels through 
the localized release of $\mathrm{TNF} \alpha$ from activated macrophages within the tumor tissue (136). The role of $\mathrm{TNF} \alpha$ in flavone anti-tumor activity was confirmed by the ability of TNF $\alpha$ antibodies to inhibit FAA-induced vascular collapse $(137,138)$. DMXAA is also thought to increase nitric oxide and serotonin as well as TNF $\alpha$ (139). The serotonin metabolite 5-hydroxyindole acetic acid (5-HIAA) is a marker of serotonin activity and is indicative of platelet activation as a result of damaged vascular endothelium. An in vivo study using a mouse model has shown that administration of DMXAA reduced tumor blood flow (as measured by DCE-MRI) and increased the 5-HIAA level. It has been suggested that 5-HIAA might be a sensitive biological marker of blood flow changes induced by DMXAA (140). One study was conducted to investigate the effects of DMXAA on tumor perfusion in cancer patients using DCE-MRI. These data have demonstrated that $50 \%$ of patients experienced up to a $66 \%$ reduction of tumor blood flow up to $24 \mathrm{~h}$ after drug infusion (141). These DCE-MRI findings are consistent with DMXAA's vascular targeting activity. Another phase I trial of 63 patients to assess DMXAA activity has shown an unconfirmed partial response in a patient with metastatic cervical cancer (142).

Two other small molecules have been shown to possess VDA-like activity; they are trivalent arsenic trioxide and the $N$-cadherin antagonist ADH-1 (Exherin; Adherex Technologies Inc). The mechanism through which arsenic trioxide elicits its vascular effects is, as yet, unknown and such effects have only been observed at doses close to the MTD in rodent tumor models (143). However, ADH-1 is a cyclic pentapeptide that competitively antagonizes $\mathrm{N}$-cadherin which mediates cell adhesion between endothelial cells as well as between endothelial cells and pericytes within the tumor vasculature. This pentapeptide contains the cadherin cell adhesion recognition sequence His-Ala-Val. An in vivo study with tumor-bearing mice has shown that $\mathrm{ADH}-1$ can induce vascular damage and extensive tumor necrosis (109). The preliminary phase I data of $\mathrm{ADH}-1$ in 46 patients with advanced solid tumors demonstrated that ADH-1 could be dose escalated as a single intravenous infusion from 50 to $1,000 \mathrm{mg} / \mathrm{m}^{2}$ without reaching the MTD (144). From these data it seems that ADH-1 is well tolerated. More research needs to be done to confirm its anti-tumor activity.

\section{Combining VDAs with anti-angiogenic drugs}

Although VDA produces extensive blood flow shutdown in general, little suppression of tumor growth has been observed following single doses. This observation has been attributed to continued proliferation of the so-called 'viable rim' of cells, which survive at the border between malignant and normal tissue. Cells in the viable rim derive their nutritional support from the vasculature associated with the normal tissue, which is not affected by VDA treatment. However, regrowth of the viable rim involves new blood vessel development; therefore, the combination of VDAs and anti-angiogenic drugs is an attractive approach that is actively being investigated.

Despite the fact that both anti-angiogenic drugs and VDAs target the tumor vasculature, it is important to recognize that key differences exist between these agents (145). These differences, as mentioned earlier in this review, apply to their mode of action as well as to their likely therapeutic applications. Taking these differences in consideration, it should be clear from a therapeutic perspective that targeting the tumor vasculature with anti-angiogenic agents and VDAs would be complimentary. Preclinical evidence supporting the notion of combining agents that target different aspects of the tumor vasculature is beginning to accumulate. For example, the effect of an anti-angiogenic drug such as bevacizumab, which targets the VEGF extracellular receptor, could be augmented with a VDA that targets the microtubular network of the endothelial cells, subsequently causing rapid vascular collapse. Since bevacizumab (anti-angiogenic agent) targets the neovascularization of the tumor, the addition of a VDA that inhibits more established tumor vascular endothelium has been suggested to have a synergistic effect (13). Indeed, it has been demonstrated that the combination of a VEGF inhibitor (ZD6474) in combination with a VDA (ZD6126) had greater anti-tumor effect than using either agent alone. This effect has been observed in preclinical human models of human renal cell carcinoma and Kaposi's sarcoma in nude mice (146).

Another example is the combination of a selective tyrosine kinase inhibitor associated with VEGFR2 and a microtubulindisrupting VDA $(69,146)$. It has been demonstrated that this combination significantly enhance tumor response beyond that achieved with either vascular targeting therapy alone. Other examples of such combinations of dual targeting of the tumor vasculature are under active preclinical investigation and these include the combination of CA4 and DMXAA with bevacizumab. The clinical testing of this concept has started with the combining of CA4P with bevacizumab in a recent a phase I clinical trial.

Nonetheless, the greatest benefits of vascular targeted therapies are expected to lie in combination with conventional anticancer therapies. Such approaches may improve treatment outcomes by capitalizing on principles of enhanced anti-tumor efficacy, non-overlapping toxicities and spatial cooperation.

The strategy of combination therapy has already started in a clinical phase I trial where single agent CA4P is also being explored with radiotherapy. In a phase I trial, patients with non-small-cell lung cancer or prostate cancer who were to receive radiotherapy were eligible for $\mathrm{CA} 4 \mathrm{P}$ treatment, which was given as a single injection to half the participants and as a weekly dose of $50 \mathrm{mg} / \mathrm{m}^{2}$ to the other half of the patients. There was a mild increase in blood pressure as well as a drop in the pulse rate after $\mathrm{CA} 4 \mathrm{P}$ administration that returned to baseline within $6 \mathrm{~h}$ after infusion. No acute or chronic toxicity was seen when CA4P was given with radiotherapy, and the cardiovascular side effects observed were mild and self-limiting (147).

Recently the development of new agents with both antiangiogenic and vascular targeting properties has attracted greater attention and a synthesized compound, C9 has been investigated as a potential candidate with anti-angiogenic activity and vascular-disruption properties (148-150). C9 is a microtubule-binding agent and effectively targets tumor vasculature. This compound impacts the morphology and function of endothelial cells, involving the Raf-MEK-ERK and Rho/Rho kinase signalling pathways (150). 


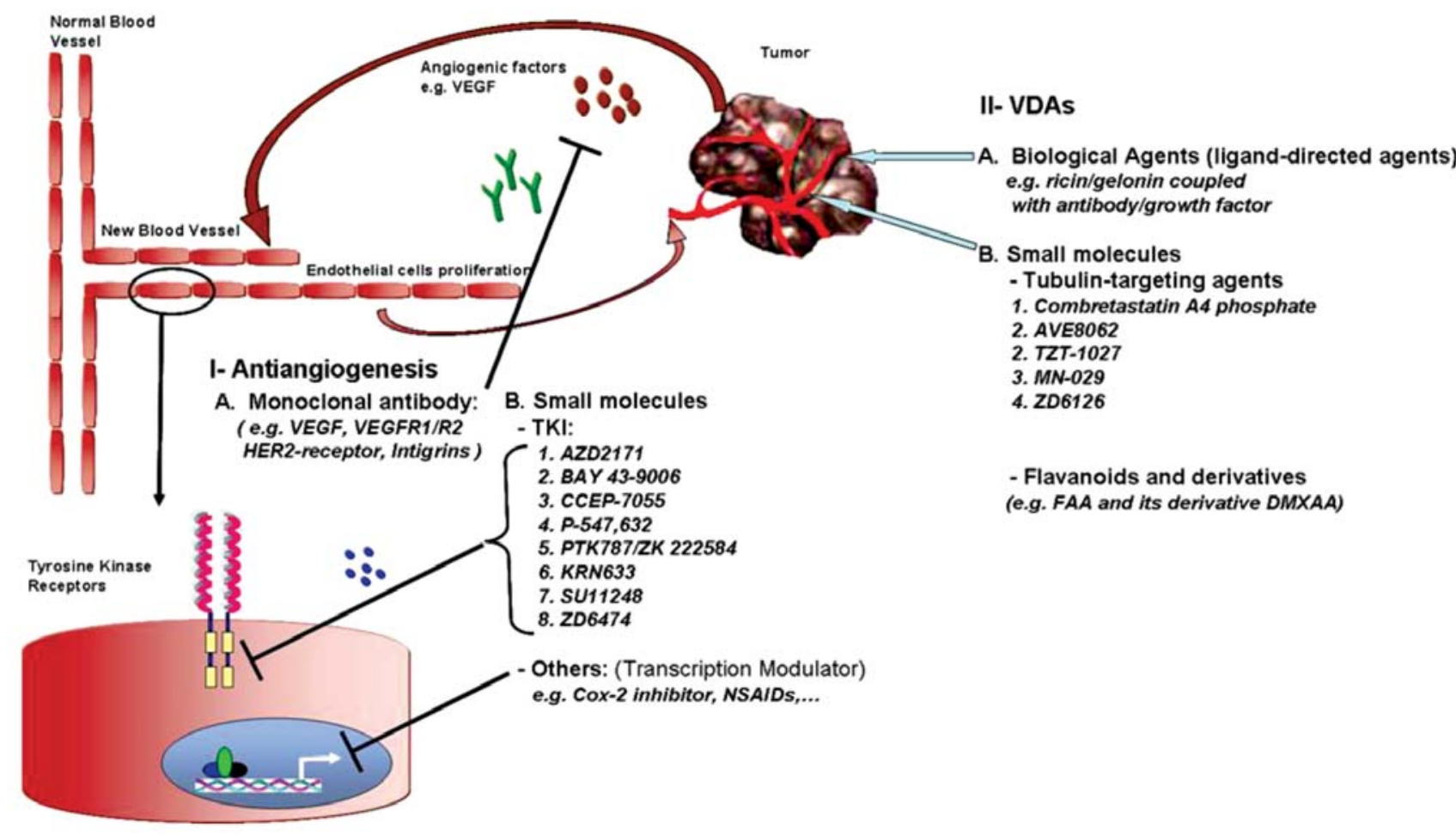

Figure 4. Schematic illustrations of several mechanisms of anti-angiogenic and vascular disrupting approaches. I, Anti-angiogenesis approach. (A) Monoclonal antibody. (B) Small molecules (tyrosine kinas inhibitors and transcription modulators). II, Vascular disrupting agents (VDAs) approach. (A) Biological agents (ligand-directed) VDA. (B) Small molecules (tubulin targeting agents and flavinoids/derivatives).

\section{Conclusions and future directions}

The ultimate goal of cytotoxic chemotherapy is to directly kill the highly dividing tumor cells. However, cytotoxic agents are often associated with drug resistance which results in tumor growth during the recovery period between doses or cycles of chemotherapy. On the other hand, strategies using antivascular novel agents (Fig. 4) that target vascular endothelial functional integrity and endothelial cell survival pathways have shown promising results in preclinical and clinical studies. Targeting the tumor endothelium and vasculature offers the attractive possibility of inducing responses in all tumor types, lowering the risk of drug resistance and improving the effectiveness of conventional clinically active cytotoxic chemotherapies.

While VDAs can kill the central, poorly perfused regions of the tumor, combination therapy with anti-angiogenic or cytotoxic agents is required to kill the well perfused, rapidly proliferating periphery of the tumor. The combinations are believed to synergistic and enhance cell killing. Based on the current preclinical data and the encouraging clinical findings anti-angiogenic agents and VDA will establish themselves as a new and distinct treatment approach in cancer therapy.

\section{Acknowledgments}

The authors wish to acknowledge M.D. Anderson Cancer Center Orlando and Florida department of Health Bankhead Coley program (07BN-01) for financial support. Authors are grateful to Donna Schade for her help in the manuscript preparation.

\section{References}

1. Shibuya M and Claesson-Welsh L: Signal transduction by VEGF receptors in regulation of angiogenesis and lymphangiogenesis. Exp Cell Res 312: 549-560, 2006.

2. Shibuya M: Vascular endothelial growth factor-dependent and -independent regulation of angiogenesis. BMB Rep 41: 278-286, 2008.

3. Folkman J: Tumor angiogenesis: therapeutic implications. $\mathrm{N}$ Engl J Med 285: 1182-1186, 1971.

4. Holash J, Wiegand SJ and Yancopoulos GD: New model of tumor angiogenesis: dynamic balance between vessel regression and growth mediated by angiopoietins and VEGF. Oncogene 18: 5356-5362, 1999.

5. Pugh CW and Ratcliffe PJ: Regulation of angiogenesis by hypoxia: role of the HIF system. Nat Med 9: 677-684, 2003.

6. Carmeliet P: Angiogenesis in health and disease. Nat Med 9: 653-660, 2003.

7. Chang DK, Chiu CY, Kuo SY, Lin WC, Lo A, Wang YP, Li PC and $\mathrm{Wu} \mathrm{HC}$ : Antiangiogenic targeting liposomes increase therapeutic efficacy for solid tumors. J Biol Chem 284: 12905-12916, 2009.

8. Kerbel R and Folkman J: Clinical translation of angiogenesis inhibitors. Nat Rev Cancer 2: 727-739, 2002.

9. Kim DK, Kinne DW and Fortner JG: Occlusion of the hepatic artery in man. Surg Gynecol Obstet 136: 966-968, 1973.

10. Marme D: The impact of anti-angiogenic agents on cancer therapy. J Cancer Res Clin Oncol 129: 607-620, 2003.

11. Sridhar SS and Shepherd FA: Targeting angiogenesis: a review of angiogenesis inhibitors in the treatment of lung cancer. Lung Cancer 42: 81-91, 2003.

12. Eskens FA: Angiogenesis inhibitors in clinical development; where are we now and where are we going? Br J Cancer 90: $1-7,2004$

13. Ellis LM, Liu W, Ahmad SA, Fan F, Jung YD, Shaheen RM and Reinmuth N: Overview of angiogenesis: biologic implications for antiangiogenic therapy. Semin Oncol 28: 94-104, 2001.

14. Ruoslahti E: Specialization of tumour vasculature. Nat Rev Cancer 2: 83-90, 2002.

15. Thorpe PE: Vascular targeting agents as cancer therapeutics. Clin Cancer Res 10: 415-427, 2004. 
16. Denekamp J: The tumour microcirculation as a target in cancer therapy: a clearer perspective. Eur J Clin Invest 29: 733-736, 1999.

17. Siemann DW, Mercer E, Lepler S and Rojiani AM: Vascular targeting agents enhance chemotherapeutic agent activities in solid tumor therapy. Int J Cancer 99: 1-6, 2002.

18. Chaplin DJ and Dougherty GJ: Tumour vasculature as a target for cancer therapy. Br J Cancer 80: 57-64, 1999

19. Siemann DW, Chaplin DJ and Horsman MR: Vascular-targeting therapies for treatment of malignant disease. Cancer 100 : 2491-2499, 2004.

20. Baguley BC: Antivascular therapy of cancer: DMXAA. Lancet Oncol 4: 141-148, 2003.

21. Liekens S, De Clercq E and Neyts J: Angiogenesis: regulators and clinical applications. Biochem Pharmacol 61: 253-270, 2001 .

22. Vaupel $P$ and Harrison L: Tumor hypoxia: causative factors, compensatory mechanisms, and cellular response. Oncologist 9: 4-9, 2004

23. Risau W: Mechanisms of angiogenesis. Nature 386: 671-674 1997.

24. Ferrara N, Gerber HP and Le Couter J: The biology of VEGF and its receptors. Nat Med 9: 669-676, 2003.

25. Ignoffo RJ: Overview of bevacizumab: a new cancer therapeutic strategy targeting vascular endothelial growth factor. Am J Health Syst Pharm 61: 21-26, 2004.

26. Hurwitz H, Fehrenbacher L, Novotny W, Cartwright T, Hainsworth J, Heim W, Berlin J, Baron A, Griffing S, Holmgren E, Ferrara N, Fyfe G, Rogers B, Ross R and Kabbinavar F: Bevacizumab plus irinotecan, fluorouracil, and leucovorin for metastatic colorectal cancer. N Engl J Med 350: 2335-2342, 2004.

27. Rugo HS: Bevacizumab in the treatment of breast cancer: rationale and current data. Oncologist 9: 43-49, 2004.

28. Ferrara N, Hillan KJ, Gerber HP and Novotny W: Discovery and development of bevacizumab, an anti-VEGF antibody for treating cancer. Nat Rev Drug Discov 3: 391-400, 2004.

29. Rini BI: VEGF-targeted therapy in metastatic renal cell carcinoma. Oncologist 10: 191-197, 2005.

30. Cabebe $\mathrm{E}$ and Wakelee $\mathrm{H}$ : Role of anti-angiogenesis agents in treating NSCLC: focus on bevacizumab and VEGFR tyrosine kinase inhibitors. Curr Treat Options Oncol 8: 15-27, 2007.

31. Johnson DH, Fehrenbacher L, Novotny WF, Herbst RS, Nemunaitis JJ, Jablons DM, Langer CJ, De Vore RF III, Gaudreault J, Damico LA, Holmgren E and Kabbinavar F: Randomized phase II trial comparing bevacizumab plus carboplatin and paclitaxel with carboplatin and paclitaxe alone in previously untreated locally advanced or metastatic non-small cell lung cancer. J Clin Oncol 22: 2184-2191, 2004.

32. Jayson GC, Zweit J, Jackson A, Mulatero C, Julyan P, Ranson M, Broughton L, Wagstaff J, Hakannson L, Groenewegen G, Bailey J, Smith N, Hastings D, Lawrance J, Haroon H, Ward T, McGown AT, Tang M, Levitt D, Marreaud S, Lehmann FF, Herold $\mathrm{M}$ and Zwierzina $\mathrm{H}$ : Molecular imaging and biological evaluation of HuMV833 anti-VEGF antibody: implications for trial design of antiangiogenic antibodies. J Natl Cancer Inst 94: 1484-1493, 2002

33. Jayson GC, Mulatero C, Ranson M, Zweit J, Jackson A, Broughton L, Wagstaff J, Hakansson L, Groenewegen G, Lawrance J, Tang M, Wauk L, Levitt D, Marreaud S, Lehmann FF, Herold $\mathrm{M}$ and Zwierzina H: Phase I investigation of recombinant anti-human vascular endothelial growth factor antibody in patients with advanced cancer. Eur J Cancer 41: 555-563, 2005

34. Zhang W, Ran S, Sambade M, Huang X and Thorpe PE: A monoclonal antibody that blocks VEGF binding to VEGFR2 (KDR/Flk-1) inhibits vascular expression of Flk-1 and tumor growth in an orthotopic human breast cancer model. Angiogenesis 5: 35-44, 2002.

35. Holash J, Davis S, Papadopoulos N, Croll SD, Ho L, Russell M, Boland P, Leidich R, Hylton D, Burova E, Ioffe E, Huang T, Radziejewski C, Bailey K, Fandl JP, Daly T, Wiegand SJ, Yancopoulos GD and Rudge JS: VEGF-Trap: a VEGF blocker with potent antitumor effects. Proc Natl Acad Sci USA 99: 11393-11398, 2002

36. Fukasawa $\mathbf{M}$ and Korc $M$ : Vascular endothelial growth factortrap suppresses tumorigenicity of multiple pancreatic cancer cell lines. Clin Cancer Res 10: 3327-3332, 2004.
37. Jain RK: Normalization of tumor vasculature: an emerging concept in antiangiogenic therapy. Science 307: 58-62, 2005.

38. Hood JD and Cheresh DA: Building a better Trap. Proc Natl Acad Sci USA 100: 8624-8625, 2003.

39. Lu D, Jimenez X, Zhang H, Bohlen P, Witte L and Zhu Z: Selection of high affinity human neutralizing antibodies to VEGFR2 from a large antibody phage display library for antiangiogenesis therapy. Int J Cancer 97: 393-399, 2002.

40. Zhu Z, Hattori K, Zhang H, Jimenez X, Ludwig DL, Dias S, Kussie P, Koo H, Kim HJ, Lu D, Liu M, Tejada R, Friedrich M, Bohlen P, Witte L and Rafii S: Inhibition of human leukemia in an animal model with human antibodies directed against vascular endothelial growth factor receptor 2. Correlation between antibody affinity and biological activity. Leukemia 17: 604-611, 2003.

41. Goldenberg MM: Trastuzumab, a recombinant DNA-derived humanized monoclonal antibody, a novel agent for the treatment of metastatic breast cancer. Clin Ther 21: 309-318, 1999.

42. Rabindran SK: Antitumor activity of HER-2 inhibitors. Cancer Lett 227: 9-23, 2005.

43. Kumar R and Yarmand-Bagheri R: The role of HER2 in angiogenesis. Semin Oncol 28: 27-32, 2001.

44. Fendly BM, Winget M, Hudziak RM, Lipari MT, Napier MA and Ullrich A: Characterization of murine monoclonal antibodies reactive to either the human epidermal growth factor receptor or HER2/neu gene product. Cancer Res 50: 1550-1558, 1990.

45. Carter P, Presta L, Gorman CM, Ridgway JB, Henner D, Wong WL, Rowland AM, Kotts C, Carver ME and Shepard HM: Humanization of an anti-p185 ${ }^{\mathrm{HER} 2}$ antibody for human cancer therapy. Proc Natl Acad Sci USA 89: 4285-4289, 1992.

46. Fischer OM, Streit S, Hart S and Ullrich A: Beyond Herceptin and Gleevec. Curr Opin Chem Biol 7: 490-495, 2003.

47. Petit AM, Rak J, Hung MC, Rockwell P, Goldstein N, Fendly B and Kerbel RS: Neutralizing antibodies against epidermal growth factor and ErbB-2/neu receptor tyrosine kinases downregulate vascular endothelial growth factor production by tumor cells in vitro and in vivo: angiogenic implications for signal transduction therapy of solid tumors. Am J Pathol 151: 1523-1530, 1997.

48. Yokoi A, McCrudden KW, Huang J, Kim ES, Soffer SZ, Frischer JS, Serur A, New T, Yuan J, Mansukhani M, O'Toole K, Yamashiro DJ and Kandel JJ: Blockade of her2/neu decreases VEGF expression but does not alter HIF-1 distribution in experimental Wilms tumor. Oncol Rep 10: 1271-1274, 2003.

49. Izumi Y, Xu L, Di Tomaso E, Fukumura D and Jain RK: Tumour biology: herceptin acts as an anti-angiogenic cocktail. Nature 416: 279-280, 2002.

50. Li J, Ji J, Holmes LM, Burgin KE, Barton LB, Yu X, Wagner TE and Wei Y: Fusion protein from RGD peptide and Fc fragment of mouse immunoglobulin $\mathrm{G}$ inhibits angiogenesis in tumor. Cancer Gene Ther 11: 363-370, 2004.

51. Nahta R, Hung MC and Esteva FJ: The HER-2-targeting antibodies trastuzumab and pertuzumab synergistically inhibit the survival of breast cancer cells. Cancer Res 64: 2343-2346, 2004.

52. Widakowich C, Dinh P, De Azambuja E, Awada A and Piccart-Gebhart M: HER-2 positive breast cancer: what else beyond trastuzumab-based therapy? Anticancer Agents Med Chem 8: 488-496, 2008.

53. Yamamoto N, Yamada Y, Fujiwara Y, Yamada K, Fujisaka Y, Shimizu T and Tamura T: Phase I and pharmacokinetic study of HER2-targeted rhuMAb 2C4 (Pertuzumab, RO4368451) in Japanese patients with solid tumors. Jpn J Clin Oncol 39: 260-266, 2009.

54. Hynes RO: A reevaluation of integrins as regulators of angiogenesis. Nat Med 8: 918-921, 2002.

55. Sipkins DA, Cheresh DA, Kazemi MR, Nevin LM, Bednarski MD and Li KC: Detection of tumor angiogenesis in vivo by alphaV beta3-targeted magnetic resonance imaging. Nat Med 4: 623-626, 1998.

56. Brooks PC, Stromblad S, Klemke R, Visscher D, Sarkar FH and Cheresh DA: Antiintegrin alpha $\mathrm{v}$ beta 3 blocks human breast cancer growth and angiogenesis in human skin. J Clin Invest 96: 1815-1822, 1995.

57. Pasqualini R, Koivunen E and Ruoslahti E: Alpha v integrins as receptors for tumor targeting by circulating ligands. Nat Biotechnol 15: 542-546, 1997. 
58. Arap W, Pasqualini R and Ruoslahti E: Cancer treatment by targeted drug delivery to tumor vasculature in a mouse model. Science 279: 377-380, 1998.

59. Hicklin DJ and Ellis LM: Role of the vascular endothelial growth factor pathway in tumor growth and angiogenesis. J Clin Oncol 23: 1011-1027, 2005.

60. Pekala P, Marlow M, Heuvelman D and Connolly D: Regulation of hexose transport in aortic endothelial cells by vascular permeability factor and tumor necrosis factor-alpha, but not by insulin. J Biol Chem 265: 18051-18054, 1990.

61. Ferrara N: Molecular and biological properties of vascular endothelial growth factor. J Mol Med 77: 527-543, 1999.

62. Wedge SR, Kendrew J, Hennequin LF, Valentine PJ, Barry ST, Brave SR, Smith NR, James NH, Dukes M, Curwen JO, Chester R, Jackson JA, Boffey SJ, Kilburn LL, Barnett S, Richmond GH, Wadsworth PF, Walker M, Bigley AL, Taylor ST, Cooper L, Beck S, Jurgensmeier JM and Ogilvie DJ: AZD2171: a highly potent, orally bioavailable, vascular endothelial growth factor receptor-2 tyrosine kinase inhibitor for the treatment of cancer. Cancer Res 65: 4389-4400, 2005.

63. Wilhelm SM, Carter C, Tang L, Wilkie D, McNabola A, Rong H, Chen C, Zhang X, Vincent P, McHugh M, Cao Y, Shujath J, Gawlak S, Eveleigh D, Rowley B, Liu L, Adnane L, Lynch M, Auclair D, Taylor I, Gedrich R, Voznesensky A, Riedl B, Post LE, Bollag G and Trail PA: BAY 43-9006 exhibits broad spectrum oral antitumor activity and targets the RAF/MEK/ERK pathway and receptor tyrosine kinases involved in tumor progression and angiogenesis. Cancer Res 64: 7099-7109, 2004.

64. Beebe JS, Jani JP, Knauth E, Goodwin P, Higdon C, Rossi AM, Emerson E, Finkelstein M, Floyd E, Harriman S, Atherton J, Hillerman S, Soderstrom C, Kou K, Gant T, Noe MC, Foster B, Rastinejad F, Marx MA, Schaeffer T, Whalen PM and Roberts WG: Pharmacological characterization of CP-547,632, a novel vascular endothelial growth factor receptor-2 tyrosine kinase inhibitor for cancer therapy. Cancer Res 63: 7301-7309, 2003.

65. Ruggeri B, Singh J, Gingrich D, Angeles T, Albom M, Yang S, Chang H, Robinson C, Hunter K, Dobrzanski P, Jones-Bolin S, Pritchard S, Aimone L, Klein-Szanto A, Herbert JM, Bono F, Schaeffer P, Casellas P, Bourie B, Pili R, Isaacs J, Ator M, Hudkins R, Vaught J, Mallamo J and Dionne C: CEP-7055: a novel, orally active pan inhibitor of vascular endothelial growth factor receptor tyrosine kinases with potent antiangiogenic activity and antitumor efficacy in preclinical models. Cancer Res 63: 5978-5991, 2003

66. Wood JM, Bold G, Buchdunger E, Cozens R, Ferrari S, Frei J, Hofmann F, Mestan J, Mett H, O'Reilly T, Persohn E, Rosel J, Schnell C, Stover D, Theuer A, Towbin H, Wenger F, WoodsCook K, Menrad A, Siemeister G, Schirner M, Thierauch KH, Schneider MR, Drevs J, Martiny-Baron G and Totzke F: PTK787/ZK 222584, a novel and potent inhibitor of vascular endothelial growth factor receptor tyrosine kinases, impairs vascular endothelial growth factor-induced responses and tumor growth after oral administration. Cancer Res 60: 2178-2189, 2000.

67. Nakamura K, Yamamoto A, Kamishohara M, Takahashi K, Taguchi E, Miura T, Kubo K, Shibuya M and Isoe T: KRN633: a selective inhibitor of vascular endothelial growth factor receptor-2 tyrosine kinase that suppresses tumor angiogenesis and growth. Mol Cancer Ther 3: 1639-1649, 2004.

68. Mendel DB, Laird AD, Xin X, Louie SG, Christensen JG, Li G, Schreck RE, Abrams TJ, Ngai TJ, Lee LB, Murray LJ, Carver J, Chan E, Moss KG, Haznedar JO, Sukbuntherng J, Blake RA, Sun L, Tang C, Miller T, Shirazian S, McMahon G and Cherrington JM: In vivo antitumor activity of SU11248, a novel tyrosine kinase inhibitor targeting vascular endothelial growth factor and platelet-derived growth factor receptors: determination of a pharmacokinetic/pharmacodynamic relationship. Clin Cancer Res 9: 327-337, 2003.

69. Carlomagno F, Vitagliano D, Guida T, Ciardiello F, Tortora G, Vecchio G, Ryan AJ, Fontanini G, Fusco A and Santoro M: ZD6474, an orally available inhibitor of KDR tyrosine kinase activity, efficiently blocks oncogenic RET kinases. Cancer Res 62: 7284-7290, 2002.

70. Ciardiello F, Caputo R, Damiano V, Caputo R, Troiani T, Vitagliano D, Carlomagno F, Veneziani BM, Fontanini G, Bianco AR and Tortora G: Antitumor effects of ZD6474, a small molecule vascular endothelial growth factor receptor tyrosine kinase inhibitor, with additional activity against epidermal growth factor receptor tyrosine kinase. Clin Cancer Res 9: 1546-1556, 2003.
71. Wedge SR, Ogilvie DJ, Dukes M, Kendrew J, Chester R, Jackson JA, Boffey SJ, Valentine PJ, Curwen JO, Musgrove HL, Graham GA, Hughes GD, Thomas AP, Stokes ES, Curry B, Richmond GH, Wadsworth PF, Bigley AL and Hennequin LF: ZD6474 inhibits vascular endothelial growth factor signaling, angiogenesis, and tumor growth following oral administration. Cancer Res 62: 4645-4655, 2002.

72. Bates D: ZD-6474. AstraZeneca. Curr Opin Investig Drugs 4: $1468-1472,2003$

73. Miller KD, Trigo JM, Wheeler C, Barge A, Rowbottom J, Sledge $\mathrm{G}$ and Baselga J: A multicenter phase II trial of ZD6474, a vascular endothelial growth factor receptor-2 and epidermal growth factor receptor tyrosine kinase inhibitor, in patients with previously treated metastatic breast cancer. Clin Cancer Res 11: 3369-3376, 2005

74. Brazelle WD, Shi W and Siemann DW: VEGF-associated tyrosine kinase inhibition increases the tumor response to single and fractionated dose radiotherapy. Int J Radiat Oncol Biol Phys 65: 836-841, 2006.

75. Rich JN, Sathornsumetee S, Keir ST, Kieran MW, Laforme A, Kaipainen A, McLendon RE, Graner MW, Rasheed BK, Wang L, Reardon DA, Ryan AJ, Wheeler C, Dimery I, Bigner DD and Friedman HS: ZD6474, a novel tyrosine kinase inhibitor of vascular endothelial growth factor receptor and epidermal growth factor receptor, inhibits tumor growth of multiple nervous system tumors. Clin Cancer Res 11: 8145-8157, 2005.

76. Vogelzang NJ: Treatment options in metastatic renal carcinoma: an embarrassment of riches. J Clin Oncol 24: 1-3, 2006.

77. Ferrara N and Kerbel RS: Angiogenesis as a therapeutic target. Nature 438: 967-974, 2005.

78. Shweiki D, Itin A, Soffer D and Keshet E: Vascular endothelial growth factor induced by hypoxia may mediate hypoxia-initiated angiogenesis. Nature 359: 843-845, 1992.

79. Rossler J, Breit S, Havers W and Schweigerer L: Vascular endothelial growth factor expression in human neuroblastoma: up-regulation by hypoxia. Int J Cancer 81: 113-117, 1999.

80. Ziemer LS, Koch CJ, Maity A, Magarelli DP, Horan AM and Evans SM: Hypoxia and VEGF mRNA expression in human tumors. Neoplasia 3: 500-508, 2001.

81. Finkenzeller G, Sparacio A, Technau A, Marme D and Siemeister G: Sp1 recognition sites in the proximal promoter of the human vascular endothelial growth factor gene are essential for platelet-derived growth factor-induced gene expression. Oncogene 15: 669-676, 1997.

82. Milanini J, Vinals F, Pouyssegur J and Pages G: p42/p44 MAP kinase module plays a key role in the transcriptional regulation of the vascular endothelial growth factor gene in fibroblasts. J Biol Chem 273: 18165-18172, 1998.

83. Fukuda R, Kelly B and Semenza GL: Vascular endothelial growth factor gene expression in colon cancer cells exposed to prostaglandin E2 is mediated by hypoxia-inducible factor 1 . Cancer Res 63: 2330-2334, 2003.

84. Schafer G, Cramer T, Suske G, Kemmner W, Wiedenmann B and Hocker M: Oxidative stress regulates vascular endothelial growth factor-A gene transcription through Sp1- and Sp3dependent activation of two proximal GC-rich promoter elements. J Biol Chem 278: 8190-8198, 2003.

85. Stoner M, Wormke M, Saville B, Samudio I, Qin C, Abdelrahim $\mathrm{M}$ and Safe S: Estrogen regulation of vascular endothelial growth factor gene expression in ZR-75 breast cancer cells through interaction of estrogen receptor alpha and SP proteins. Oncogene 23: 1052-1063, 2004.

86. Abdelrahim M, Smith R III, Burghardt R and Safe S: Role of Sp proteins in regulation of vascular endothelial growth factor expression and proliferation of pancreatic cancer cells. Cancer Res 64: 6740-6749, 2004.

87. Ishibashi H, Nakagawa K, Onimaru M, Castellanous EJ, Kaneda Y, Nakashima Y, Shirasuna K and Sueishi K: Sp1 decoy transfected to carcinoma cells suppresses the expression of vascular endothelial growth factor, transforming growth factor beta1, and tissue factor and also cell growth and invasion activities. Cancer Res 60: 6531-6536, 2000.

88. Gately S and Li WW: Multiple roles of COX-2 in tumor angiogenesis: a target for antiangiogenic therapy. Semin Oncol 31: 2-11, 2004.

89. Taketo MM: COX-2 and colon cancer. Inflamm Res 47 (Suppl. 2): S112-S116, 1998 
90. Wei D, Wang L, He Y, Xiong HQ, Abbruzzese JL and Xie K Celecoxib inhibits vascular endothelial growth factor expression in and reduces angiogenesis and metastasis of human pancreatic cancer via suppression of Sp1 transcription factor activity. Cancer Res 64: 2030-2038, 2004.

91. Abdelrahim M and Safe S: Cyclooxygenase-2 inhibitors decrease vascular endothelial growth factor expression in colon cancer cells by enhanced degradation of $\mathrm{Sp} 1$ and $\mathrm{Sp} 4$ proteins. Mol Pharmacol 68: 317-329, 2005.

92. Abdelrahim M, Baker CH, Abbruzzese JL and Safe S: Tolfenamic acid and pancreatic cancer growth, angiogenesis, and Sp protein degradation. J Natl Cancer Inst 98: 855-868, 2006.

93. Konduri S, Colon J, Baker CH, Safe S, Abbruzzese JL, Abudayyeh A, Basha MR and Abdelrahim M: Tolfenamic acid enhances pancreatic cancer cell and tumor response to radiation therapy by inhibiting survivin protein expression. Mol Cancer Ther 8: 533-542, 2009.

94. Benjamin LE, Golijanin D, Itin A, Pode D and Keshet E: Selective ablation of immature blood vessels in established human tumors follows vascular endothelial growth factor withdrawal. J Clin Invest 103: 159-165, 1999.

95. Pluda JM: Tumor-associated angiogenesis: mechanisms, clinical implications, and therapeutic strategies. Semin Oncol 24: 203-218, 1997.

96. Jain RK: Molecular regulation of vessel maturation. Nat Med 9: 685-693, 2003.

97. Neri D and Bicknell R: Tumour vascular targeting. Nat Rev Cancer 5: 436-446, 2005

98. Matsumura Y and Maeda $\mathrm{H}$ : A new concept for macromolecular therapeutics in cancer chemotherapy: mechanism of tumoritropic accumulation of proteins and the antitumor agent smancs. Cancer Res 46: 6387-6392, 1986.

99. Darland DC and D'Amore PA: Blood vessel maturation: vascular development comes of age. J Clin Invest 103: 157-158, 1999.

100. Morikawa S, Baluk P, Kaidoh T, Haskell A, Jain RK and McDonald DM: Abnormalities in pericytes on blood vessels and endothelial sprouts in tumors. Am J Pathol 160: 985-1000, 2002.

101. Kakolyris S, Fox SB, Koukourakis M, Giatromanolaki A, Brown N, Leek RD, Taylor M, Leigh IM, Gatter KC and Harris AL: Relationship of vascular maturation in breast cancer blood vessels to vascular density and metastasis, assessed by expression of a novel basement membrane component, LH39. Br J Cancer 82: 844-851, 2000.

102. Schnitzer JE: Vascular targeting as a strategy for cancer therapy. N Engl J Med 339: 472-474, 1998.

103. Griggs J, Metcalfe JC and Hesketh R: Targeting tumour vasculature: the development of combretastatin A4. Lancet Oncol 2: 82-87, 2001

104. Tozer GM, Kanthou C, Parkins CS and Hill SA: The biology of the combretastatins as tumour vascular targeting agents. Int J Exp Pathol 83: 21-38, 2002.

105. Huang X, Molema G, King S, Watkins L, Edgington TS and Thorpe PE: Tumor infarction in mice by antibody-directed targeting of tissue factor to tumor vasculature. Science 275: $547-550,1997$.

106. Blakey DC, Westwood FR, Walker M, Hughes GD, Davis PD, Ashton SE and Ryan AJ: Antitumor activity of the nove vascular targeting agent ZD6126 in a panel of tumor models. Clin Cancer Res 8: 1974-1983, 2002.

107. Ching LM, Goldsmith D, Joseph WR, Korner H, Sedgwick JD and Baguley BC: Induction of intratumoral tumor necrosis factor (TNF) synthesis and hemorrhagic necrosis by 5,6 dimethylxanthenone-4-acetic acid (DMXAA) in TNF knockout mice. Cancer Res 59: 3304-3307, 1999.

108. Thorpe PE, Chaplin DJ and Blakey DC: The first international conference on vascular targeting: meeting overview. Cancer Res 63: 1144-1147, 2003.

109. Pasqualini R and Arap W: Translation of vascular diversity into targeted therapeutics. Ann Hematol 81: 66-67, 2002.

110. Trepel M, Arap W and Pasqualini R: Exploring vascular heterogeneity for gene therapy targeting. Gene Ther 7: 2059-2060, 2000 .

111. Nilsson F, Kosmehl H, Zardi L and Neri D: Targeted delivery of tissue factor to the ED-B domain of fibronectin, a marker of angiogenesis, mediates the infarction of solid tumors in mice. Cancer Res 61: 711-716, 2001.

112. Huang X, Bennett M and Thorpe PE: A monoclonal antibody that binds anionic phospholipids on tumor blood vessels enhances the antitumor effect of docetaxel on human breast tumors in mice. Cancer Res 65: 4408-4416, 2005.
113. Arap W, Kolonin MG, Trepel M, Lahdenranta J, Cardo-Vila M, Giordano RJ, Mintz PJ, Ardelt PU, Yao VJ, Vidal CI, Chen L, Flamm A, Valtanen H, Weavind LM, Hicks ME, Pollock RE, Botz GH, Bucana CD, Koivunen E, Cahill D, Troncoso P, Baggerly KA, Pentz RD, Do KA, Logothetis CJ and Pasqualini R: Steps toward mapping the human vasculature by phage display. Nat Med 8: 121-127, 2002.

114. Chaplin DJ, Pettit GR, Parkins CS and Hill SA: Antivascular approaches to solid tumour therapy: evaluation of tubulin binding agents. Br J Cancer (Suppl) 27: 86-88, 1996.

115. Hill SA, Sampson LE and Chaplin DJ: Anti-vascular approaches to solid tumour therapy: evaluation of vinblastine and flavone acetic acid. Int J Cancer 63: 119-123, 1995.

116. Kerr DJ and Kaye SB: Flavone acetic acid - preclinical and clinical activity. Eur J Cancer Clin Oncol 25: 1271-1272, 1989.

117. Chabot GG, Branellec D, Sassi A, Armand JP, Gouyette A and Chouaib S: Tumour necrosis factor-alpha plasma levels after flavone acetic acid administration in man and mouse. Eur J Cancer 29: 729-733, 1993.

118. Hill SA, Toze GM, Pettit GR and Chaplin DJ: Preclinical evaluation of the antitumour activity of the novel vascular targeting agent Oxi 4503. Anticancer Res 22: 1453-1458, 2002.

119. Baguley BC, Holdaway KM, Thomsen LL, Zhuang L and Zwi LJ: Inhibition of growth of colon 38 adenocarcinoma by vinblastine and colchicine: evidence for a vascular mechanism. Eur J Cancer 27: 482-487, 1991.

120. Hill SA, Lonergan SJ, Denekamp J and Chaplin DJ: Vinca alkaloids: anti-vascular effects in a murine tumour. Eur J Cancer 29: 1320-1324, 1993

121. Bibby MC, Double JA, Loadman PM and Duke CV: Reduction of tumor blood flow by flavone acetic acid: a possible component of therapy. J Natl Cancer Inst 81: 216-220, 1989.

122. Kallinowski F, Schaefer C, Tyler G and Vaupel P: In vivo targets of recombinant human tumour necrosis factor-alpha: blood flow, oxygen consumption and growth of isotransplanted rat tumours. Br J Cancer 60: 555-560, 1989.

123. Zwi LJ, Baguley BC, Gavin JB and Wilson WR: Blood flow failure as a major determinant in the antitumor action of flavone acetic acid. J Natl Cancer Inst 81: 1005-1013, 1989.

124. Dark GG, Hill SA, Prise VE, Tozer GM, Pettit GR and Chaplin DJ: Combretastatin A-4, an agent that displays potent and selective toxicity toward tumor vasculature. Cancer Res 57: 1829-1834, 1997.

125. Chaplin DJ, Pettit GR and Hill SA: Anti-vascular approaches to solid tumour therapy: evaluation of combretastatin A4 phosphate. Anticancer Res 19: 189-195, 1999.

126. Russell GJ and Lacey E: Inhibition of $\left[{ }^{3} \mathrm{H}\right]$ mebendazole binding to tubulin by structurally diverse microtubule inhibitors which interact at the colchicine binding site. Biochem Mol Biol Int 35: 1153-1159, 1995.

127. James C, Pettit GR, Nielsen OF, Jayakumar VS and Joe IH: Vibrational spectra and ab initio molecular orbital calculations of the novel anti-cancer drug combretastatin A-4 prodrug. Spectrochim Acta A Mol Biomol Spectrosc 70: 1208-1216, 2008.

128. Siemann DW, Chaplin DJ and Walicke PA: A review and update of the current status of the vasculature-disabling agent combretastatin-A4 phosphate (CA4P). Expert Opin Investig Drugs 18: 189-197, 2009.

129. Vincent L, Kermani P, Young LM, Cheng J, Zhang F, Shido K, Lam G, Bompais-Vincent H, Zhu Z, Hicklin DJ, Bohlen P, Chaplin DJ, May C and Rafii S: Combretastatin A4 phosphate induces rapid regression of tumor neovessels and growth through interference with vascular endothelial-cadherin signaling. J Clin Invest 115: 2992-3006, 2005.

130. Dowlati A, Robertson K, Cooney M, Petros WP, Stratford M, Jesberger J, Rafie N, Overmoyer B, Makkar V, Stambler B, Taylor A, Waas J, Lewin JS, McCrae KR and Remick SC: A phase I pharmacokinetic and translational study of the novel vascular targeting agent combretastatin a-4 phosphate on a single-dose intravenous schedule in patients with advanced cancer. Cancer Res 62: 3408-3416, 2002.

131. Anderson HL, Yap JT, Miller MP, Robbins A, Jones T and Price PM: Assessment of pharmacodynamic vascular response in a phase I trial of combretastatin A4 phosphate. J Clin Oncol 21: 2823-2830, 2003.

132. Otani M, Natsume T, Watanabe JI, Kobayashi M, Murakoshi M, Mikami T and Nakayama T: TZT-1027, an antimicrotubule agent, attacks tumor vasculature and induces tumor cell death. Jpn J Cancer Res 91: 837-844, 2000. 
133. Schoffski P, Riggert S, Fumoleau P, Campone M, Bolte O, Marreaud S, Lacombe D, Baron B, Herold M, Zwierzina $\mathrm{H}$, Wilhelm-Ogunbiyi K, Lentzen $\mathrm{H}$ and Twelves $\mathrm{C}$ : Phase I trial of intravenous aviscumine (rViscumin) in patients with solid tumors: a study of the European Organization for Research and Treatment of Cancer New Drug Development Group. Ann Oncol 15: 1816-1824, 2004

134. De Jonge MJ, van der Gaast A, Planting AS, van Doorn L, Lems A, Boot I, Wanders J, Satomi M and Verweij J: Phase I and pharmacokinetic study of the dolastatin 10 analogue TZT-1027, given on days 1 and 8 of a 3 -week cycle in patients with advanced solid tumors. Clin Cancer Res 11: 3806-3813, 2005.

135. Davis PD, Dougherty GJ, Blakey DC, Galbraith SM, Tozer GM, Holder AL, Naylor MA, Nolan J, Stratford MR, Chaplin DJ and Hill SA: ZD6126: a novel vascular-targeting agent that causes selective destruction of tumor vasculature. Cancer Res 62: 7247-7253, 2002.

136. Baguley BC and Ching LM: DMXAA: an antivascular agent with multiple host responses. Int J Radiat Oncol Biol Phys 54: 1503-1511, 2002.

137. Mahadevan V, Malik ST, Meager A, Fiers W, Lewis GP and Hart IR: Role of tumor necrosis factor in flavone acetic acidinduced tumor vasculature shutdown. Cancer Res 50: 5537-5542, 1990.

138. Philpott M, Baguley BC and Ching LM: Induction of tumour necrosis factor-alpha by single and repeated doses of the antitumour agent 5,6-dimethylxanthenone-4-acetic acid. Cancer Chemother Pharmacol 36: 143-148, 1995.

139. Zhou S, Kestell P, Baguley BC and Paxton JW: 5,6dimethylxanthenone-4-acetic acid (DMXAA): a new biological response modifier for cancer therapy. Invest New Drugs 20: 281-295, 2002.

140. McPhail LD, McIntyre DJ, Ludwig C, Kestell P, Griffiths JR, Kelland LR and Robinson SP: Rat tumor response to the vascular-disrupting agent 5,6-dimethylxanthenone-4-acetic acid as measured by dynamic contrast-enhanced magnetic resonance imaging, plasma 5-hydroxyindoleacetic acid levels, and tumor necrosis. Neoplasia 8: 199-206, 2006.

141. Galbraith SM, Rustin GJ, Lodge MA, Taylor NJ, Stirling JJ, Jameson M, Thompson P, Hough D, Gumbrell L and Padhani AR: Effects of 5,6-dimethylxanthenone-4-acetic acid on human tumor microcirculation assessed by dynamic contrast-enhanced magnetic resonance imaging. J Clin Oncol 20: 3826-3840, 2002.
142. Jameson MB, Thompson PI, Baguley BC, Evans BD, Harvey VJ, Porter DJ, McCrystal MR, Small M, Bellenger K, Gumbrell L, Halbert GW and Kestell P: Clinical aspects of a phase I trial of 5,6-dimethylxanthenone-4-acetic acid (DMXAA), a novel antivascular agent. Br J Cancer 88: 1844-1850, 2003.

143. Griffin RJ, Monzen H, Williams BW, Park H, Lee SH and Song CW: Arsenic trioxide induces selective tumour vascular damage via oxidative stress and increases thermosensitivity of tumours. Int J Hyperthermia 19: 575-589, 2003.

144. Maroun JA, Jonker D, Seymour L, Goel R, Vincent M, Kocha W, Cripps C, Fisher B, Lister D, Malpage A and Chiritescu G: A National Cancer Institute of Canada Clinical Trials Group Study-IND.135: phase I/II study of irinotecan (camptosar), oxaliplatin and raltitrexed (tomudex) (COT) in patients with advanced colorectal cancer. Eur J Cancer 42: 193-199, 2006.

145. Siemann DW, Bibby MC, Dark GG, Dicker AP, Eskens FA, Horsman MR, Marme D and Lorusso PM: Differentiation and definition of vascular-targeted therapies. Clin Cancer Res 11: 416-420, 2005

146. Siemann DW and Shi W: Efficacy of combined antiangiogenic and vascular disrupting agents in treatment of solid tumors. Int J Radiat Oncol Biol Phys 60: 1233-1240, 2004.

147. Cooney MM, Ortiz J, Bukowski RM and Remick SC: Novel vascular targeting/disrupting agents: combretastatin A4 phosphate and related compounds. Curr Oncol Rep 7: 90-95, 2005 .

148. Belleri M, Ribatti D, Nicoli S, Cotelli F, Forti L, Vannini V, Stivala LA and Presta M: Antiangiogenic and vasculartargeting activity of the microtubule-destabilizing transresveratrol derivative 3,5,4'-trimethoxystilbene. Mol Pharmacol 67: 1451-1459, 2005.

149. Kruczynski A, Poli M, Dossi R, Chazottes E, Berrichon G, Ricome C, Giavazzi R, Hill BT and Taraboletti G: Antiangiogenic, vascular-disrupting and anti-metastatic activities of vinflunine, the latest vinca alkaloid in clinical development. Eur J Cancer 42: 2821-2832, 2006.

150. Ren X, Dai M, Lin LP, Li PK and Ding J: Anti-angiogenic and vascular disrupting effects of $\mathrm{C} 9$, a new microtubuledepolymerizing agent. Br J Pharmacol (In press). 